\title{
A Methodology for Architecture Theory and Practices Research: Design Practices Evaluation Studio
}

\author{
Fathi Bashier ${ }^{1}$
}

\begin{abstract}
This article presents the initial findings of the design research carried out during the last semester by the master of architecture students at Wollega University, Ethiopia. The research goal is the creation of new knowledge to improve the design process. The dissatisfaction with the outcomes of the conventional design approach has led to rising concern and growing awareness of the need to evaluate design outcomes and to learn from the failure. That inadequate understanding of design problems leads frequently to design failure suggests that the evaluation of design outcomes can be made by assessing the way architects develop understanding of design problems, and how they use that understanding for developing knowledge base of the design process. The assumption is that architects' understanding of design problems can be assessed by examining the way data is used for developing the knowledge base of the design process. The students surveyed the architects' views in order to produce knowledge, which can be used to develop methods for discovering how inadequate data contributes to miss-informed design decisions; and methods for assessing the architects' understanding of design problems. In this article the survey findings are analyzed and documented; and, the way the insight drawn from the inquiry can be used in future research for developing design theory, is discussed.
\end{abstract}

Keywords: design outcomes, failure, evaluation, questionnaire, analyze

\section{Introduction}

This article presents the initial findings of the design research work, which has been carried out during the last semester by the master of architecture students at Wollega University, Ethiopia. The research goal is the creation and advancement of new knowledge, creating and testing design methods. The focus in this article is the knowledge which results from research into existing design practices.

The dissatisfaction with the outcomes of the conventional design approach has recently led to rising concern in the studio and growing awareness that there is a pressing need to evaluate design outcomes and to learn from the failure. That inadequate understanding of design problems leads frequently to design failure, as Friedman (2000:20) says, suggests that the evaluation of design failure can be achieved by assessing the way architects develop the understanding of design problems, and how they use that understanding for developing knowledge base of the design process. This proposition has influenced the research strategy, which is focused on developing methods for the evaluation of design outcomes, and methods for using that understanding to develop a base knowledge for the creation of descriptive theories, in future research.

The assumption is that design outcomes can be evaluated by assessing the way architects develop understanding of design problems, and how they produce design knowledge. This requires examining the way they collect and analyze data, and the quality of data 
they use to inform design decisions. For the validation of the research assumption, an empirical evaluation of existing design outcomes has been carried out by the master students.

The students have been engaged during the past semester in studying existing case studies, examining specific design problems that are associated with and likely causing observed failure. They have used questionnaires and interviewed those concerned including the users, administrators and the architects. The survey aimed to produce empirical knowledge that the study can use to develop methods. Firstly, methods for assessing the way architects develop understanding of design problems; and secondly methods for using that understanding, in a future research, to develop the knowledge base of the design process. In this article the survey findings are analyzed and documented; and, the way the insight drawn from the inquiry can be used for developing methods, in future research, for creating and testing design theory is discussed.

\section{Design Practices Evaluation}

The master students have been carrying an empirical evaluation of existing design outcomes over the past semester. The evaluation of design outcomes has been made on basis of assessing the architect's understanding of design problems, with emphasis on specific problems associated with design failure. The students were required to investigate specific research problems of their own choice based on observation, and to answer some of the following questions put forward by the studio as a guide, including: what design failure is? what is the lacking data that led to miss-informed design decision? how has the missing data impacted design decisions? what are the sources from which lacking data has led to miss-informed design decisions? What are the reasons of missing data?

21 students have participated in the survey and conducted 63 case-studies over the past semester. They used questionnaires and interviewed 20 architects to survey their views regarding the significance of the different types of data they used in the design process. The inquiry aimed to discover the way the failure to use adequate design data might have impacted design decisions and led ultimately to failure.

The students were asked to make analysis of the different types of data that the architects used to develop the knowledge base of the design process. They were able to use the analysis of the survey output in measuring the degree as to which lacking specific data has led to miss-informed design decisions and ultimately design failure. The analysis provided insight into the way the architects value the different types of data for reaching a successful design outcome.

Seven questionnaire models were prepared by the studio (Tables:1-7). The questionnaires contained a similar list of data organized under ten categories. The architects were asked to respond to the questionnaires as follows:

- the $1^{\text {st }}$ questionnaire requires the surveyed architects to indicate the different types of data they collected, analyzed and used in the design process. The questionnaire serves two goals. First, it measures the architects' competency based on the degree of inclusiveness of the data they acquired. The full list of data was given the total mark $100 \%$, which was divided into 10 categories of $10 \%$ each. Architects' competence was 
then graded according to the scale of competence, relative to the number of categories they acquired data from. The second goal of this questionnaire identifies the types of data that was not considered in the design process of each case study in question.

- the $2^{\text {nd }}$ questionnaire requires the architects to indicate the sources they relied on most in obtaining the different types of data needed for the design process. There are 5 data sources listed in this questionnaire, which were given a full mark of $100 \%$. The full data sources mark was divided into 5 of $20 \%$ percent divisions, which correspond with 5 data sources, namely: the brief, the users, the literature and design documents, design appraisal, and tacit personal experience. This questionnaire measures the quality of data on basis of type and sources. The architects' competence here is measured relative to the quality of data, which is in turn based on the variety and types of data sources.

- table:3 sums up the architects' competence, according to the scale of competence, based on the inclusiveness of the data they used, and on the sources of data obtained.

- The $4^{\text {th }}$ questionnaire requires the architects to indicate the significance of the different types of data they collect and use in the design process graded as: highly significant, significant, moderately significant, less significant.

- The $5^{\text {th }}$ questionnaire requires the architects to indicate the impact of the missing data on design decisions, graded as: highly detrimental, detrimental, moderately detrimental, less detrimental.

- the $6^{\text {th }}$ questionnaire measures the frequency of coding, recording, and re-using of research data.

- the $7^{\text {th }}$ questionnaire measures the frequency of the architects participation in POE evaluation.

Table (1): architect's competency based on data inclusiveness

Please put $(\mathrm{X})$ to mark the data needed for the design process and obtained by architects

\begin{tabular}{|c|c|c|c|c|c|c|c|c|c|}
\hline & \multicolumn{2}{|l|}{ Architects code nos. } & \multirow[t]{2}{*}{ Arch1 } & \multirow[t]{2}{*}{ Arch2 } & \multirow[t]{2}{*}{ Arch3 } & \multirow[t]{2}{*}{ Arch4 } & \multirow[t]{2}{*}{ Arch5 } & \multirow[t]{2}{*}{ Arch6 } & \multirow[t]{2}{*}{ Arch7 } \\
\hline & Competence score & $\%$ & & & & & & & \\
\hline \multirow[t]{2}{*}{1} & Social & $10 \%$ & & & & & & & \\
\hline & Users' need, activities & & & & & & & & \\
\hline \multirow[t]{3}{*}{2} & Cultural & $10 \%$ & & & & & & & \\
\hline & Regional architecture & & & & & & & & \\
\hline & Heritage & & & & & & & & \\
\hline \multirow[t]{2}{*}{3} & Economic & $10 \%$ & & & & & & & \\
\hline & Cost effectiveness & & & & & & & & \\
\hline \multirow[t]{2}{*}{4} & Environment & $10 \%$ & & & & & & & \\
\hline & $\begin{array}{l}\text { Sustainability, } \\
\text { Green design, } \\
\text { Energy efficiency }\end{array}$ & & & & & & & & \\
\hline \multirow[t]{4}{*}{5} & Urban & $10 \%$ & & & & & & & \\
\hline & Urban environment & & & & & & & & \\
\hline & $\begin{array}{l}\text { Site location, } \\
\text { Infra-structure }\end{array}$ & & & & & & & & \\
\hline & Natural landscape & & & & & & & & \\
\hline \multirow[t]{2}{*}{6} & Structural & $10 \%$ & & & & & & & \\
\hline & Structural stability & & & & & & & & \\
\hline
\end{tabular}




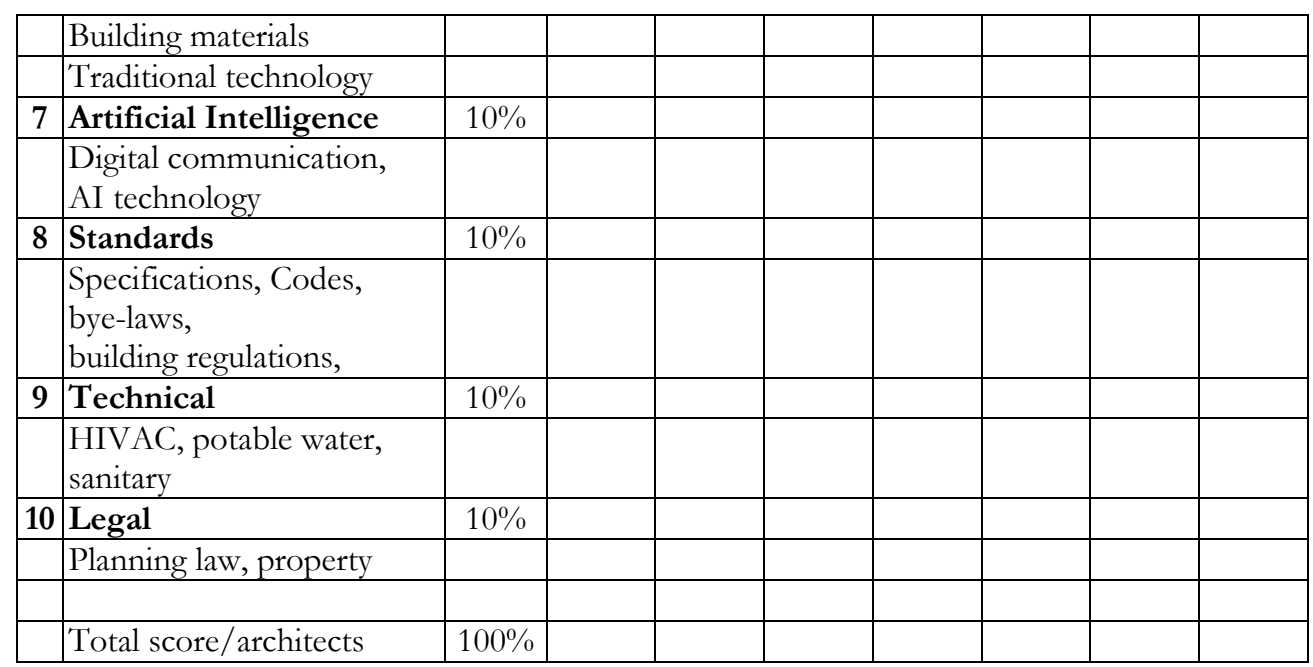

Scale of competence: $80 \%$ v. competent, $60 \%$ competent, $40 \%$ incompetent, $20 \%$ v. incompetent

Table (2): sources of data

Please mark as $(1,2,3,4,5)$ to indicate the sources, which the architects relied on most in obtaining the data for the design process

\begin{tabular}{|c|c|c|c|c|c|c|}
\hline $\begin{array}{l}\text { Arch code } \\
\text { nos. }\end{array}$ & $\begin{array}{l}\text { The } \\
\text { brief }\end{array}$ & $\begin{array}{l}\text { The } \\
\text { users }\end{array}$ & $\begin{array}{c}\text { The literature \& } \\
\text { Design documents }\end{array}$ & $\begin{array}{c}\text { Design } \\
\text { appraisal }\end{array}$ & $\begin{array}{c}\text { Tacit } \\
\text { experience }\end{array}$ & $\begin{array}{l}\text { Total } \\
\text { score }\end{array}$ \\
\hline & $20 \%$ & $20 \%$ & $20 \%$ & $20 \%$ & $20 \%$ & $100 \%$ \\
\hline Arch1 & & & & & & \\
\hline Arch2 & & & & & & \\
\hline Arch3 & & & & & & \\
\hline Arch4 & & & & & & \\
\hline Arch5 & & & & & & \\
\hline Arch6 & & & & & & \\
\hline Arch7 & & & & & & \\
\hline Arch8 & & & & & & \\
\hline Arch9 & & & & & & \\
\hline Arch10 & & & & & & \\
\hline
\end{tabular}

Table (3): architect's competency based on inclusiveness and sources of data

\begin{tabular}{|l|c|c|c|c|}
\hline $\begin{array}{l}\text { architects/ no. } \\
\text { variables }\end{array}$ & $\begin{array}{c}\text { very } \\
\text { competent }\end{array}$ & competent & incompetent & $\begin{array}{c}\text { very } \\
\text { incompetent }\end{array}$ \\
\hline Data quality & 2 & 4 & 8 & 6 \\
\hline Data inclusiveness & 2 & 4 & 8 & 6 \\
\hline
\end{tabular}

Scale of competence: $80 \%$ v. competent, $60 \%$ competent, $40 \%$ incompetent, $20 \% \mathrm{v}$. incomplete 
Table (4): Types of data and their significance for the design process

\begin{tabular}{|c|c|c|c|c|c|}
\hline \multicolumn{6}{|c|}{ Please mark by $(\mathrm{X})$ to indicate the significance of data obtained for design decisions } \\
\hline & & $\begin{array}{l}\text { Highly } \\
\text { significant }\end{array}$ & significant & $\begin{array}{c}\text { Moderately } \\
\text { significant }\end{array}$ & $\begin{array}{c}\text { Less } \\
\text { significant }\end{array}$ \\
\hline & Competence score & & & & \\
\hline \multirow[t]{2}{*}{1} & Social & & & & \\
\hline & Users' need, activities & & & & \\
\hline \multirow[t]{3}{*}{2} & Cultural & & & & \\
\hline & Regional architecture & & & & \\
\hline & Heritage & & & & \\
\hline \multirow[t]{2}{*}{3} & Economic & & & & \\
\hline & Cost effectiveness & & & & \\
\hline \multirow[t]{2}{*}{4} & Environment & & & & \\
\hline & $\begin{array}{l}\text { Sustainability, } \\
\text { Green design, } \\
\text { Energy efficiency }\end{array}$ & & & & \\
\hline \multirow[t]{4}{*}{5} & Urban & & & & \\
\hline & Urban environment & & & & \\
\hline & $\begin{array}{l}\text { Site location, } \\
\text { Infra-structure }\end{array}$ & & & & \\
\hline & Natural landscape & & & & \\
\hline \multirow[t]{4}{*}{6} & Structural & & & & \\
\hline & Structural stability & & & & \\
\hline & Building materials & & & & \\
\hline & Traditional technology & & & & \\
\hline \multirow[t]{2}{*}{7} & Artificial Intelligence & & & & \\
\hline & $\begin{array}{l}\text { Digital communication, } \\
\text { AI technology }\end{array}$ & & & & \\
\hline \multirow[t]{2}{*}{8} & Standards & & & & \\
\hline & $\begin{array}{l}\text { Specifications, Codes, } \\
\text { bye-laws, } \\
\text { building regulations, }\end{array}$ & & & & \\
\hline \multirow[t]{2}{*}{9} & Technical & & & & \\
\hline & $\begin{array}{l}\text { HIVAC, potable water, } \\
\text { sanitary }\end{array}$ & & & & \\
\hline \multirow[t]{2}{*}{10} & Legal & & & & \\
\hline & Planning law, property & & & & \\
\hline
\end{tabular}

Table (5): Types of missing data and the impact on design decisions

\begin{tabular}{|c|l|l|l|l|c|}
\hline \multicolumn{5}{|c|}{ Please mark by $(\mathrm{X})$ to indicate the impact of missing data on design decisions } \\
\hline & $\begin{array}{c}\text { Highly } \\
\text { detrimental }\end{array}$ & detrimental & $\begin{array}{c}\text { Moderately } \\
\text { detrimental }\end{array}$ & $\begin{array}{c}\text { Less } \\
\text { detrimental }\end{array}$ \\
\hline & Competence score & & & & \\
\hline 1 & Social & & & & \\
\hline & Users' need, activities & & & & \\
\hline 2 & Cultural & & & & \\
\hline & Regional architecture & & & & \\
\hline & Heritage & & & & \\
\hline
\end{tabular}




\begin{tabular}{|c|l|l|l|l|l|}
\hline 3 & Economic & & & \\
\hline & Cost effectiveness & & & & \\
\hline 4 & Environment & & & \\
\hline & $\begin{array}{l}\text { Sustainability, } \\
\text { Green design, } \\
\text { Energy efficiency }\end{array}$ & & & & \\
\hline 5 & Urban & & & & \\
\hline & Urban environment & & & & \\
\hline & Site location, & & & \\
\hline & Nnfra-structure & Natural landscape & & & \\
\hline 6 & Structural & & & & \\
\hline & Structural stability & & & & \\
\hline & Building materials & & & & \\
\hline & Traditional technology & & & & \\
\hline 7 & Artificial Intelligence & & & & \\
\hline & $\begin{array}{l}\text { Digital communication, } \\
\text { AI technology }\end{array}$ & & & & \\
\hline 8 & Standards & & & \\
\hline & $\begin{array}{l}\text { Specifications, Codes, } \\
\text { bye-laws, } \\
\text { building regulations, }\end{array}$ & & & & \\
\hline 9 & Technical & & & \\
\hline & $\begin{array}{l}\text { HIVAC, potable water, } \\
\text { sanitary }\end{array}$ & & & & \\
\hline 10 & Legal & & & & \\
\hline & Planning law, property & & & & \\
\hline
\end{tabular}

Table (6): the frequency of coding, recording, and re-using research data in new projects?

\begin{tabular}{|l|l|l|l|l|}
\hline \multicolumn{5}{|c|}{ Please put $(\mathrm{X})$ to mark the frequency of data coding, recording, and re-using in new projects? } \\
\hline Arch. code nos. & frequently & regularly & occasionally & rarely \\
\hline Arch1 & & & & \\
\hline Arch2 & & & & \\
\hline Arch3 & & & & \\
\hline Arch4 & & & & \\
\hline Arch5 & & & & \\
\hline Arch6 & & & & \\
\hline Arch7 & & & & \\
\hline Arch8 & & & & \\
\hline Arch9 & & & & \\
\hline Arch10 & & & & \\
\hline Total/ architects & & & & \\
\hline
\end{tabular}

Table (7): frequency of participation in POE projects evaluation

\begin{tabular}{|l|l|l|l|l|}
\hline \multicolumn{4}{|c|}{ Please put $(\mathrm{X})$ to mark the frequency of your participation in POE projects evaluation } \\
\hline Arch. code nos. & frequently & regularly & occasionally & Rarely \\
\hline Arch1 & & & & \\
\hline Arch2 & & & & \\
\hline Arch3 & & & & \\
\hline Arch4 & & & & \\
\hline
\end{tabular}




\begin{tabular}{|l|l|l|l|l|}
\hline Arch5 & & & & \\
\hline Arch6 & & & & \\
\hline Arch7 & & & & \\
\hline Arch8 & & & & \\
\hline Arch9 & & & & \\
\hline Arch10 & & & & \\
\hline Total/ architects & & & \\
\hline
\end{tabular}

\subsection{The survey analysis}

21 students have participated in the survey. They conducted 63 case-studies and interviewed 20 architects. The aim of the survey was to answer some of the questions put forward by the study, mentioned before. They are now engaged in analyzing the survey feedback. The analysis involves comparing the response of the different participants, users' statements, in addition to the students own observation of the actual conditions on the ground. The findings can be summarized as follows:

Most responses reflected high concern for functional space planning and for the activities that are supposed to take place inside them. However, the reality as the case studies showed is that attention is not given to good space design especially in public buildings such as hospitals. Observation indicates that most design failure result from the failure to satisfy the users' social need such as information facilities, waiting areas, toilets, etc.

The survey responses showed that the most frequent areas of architects' interest are technical in nature including, construction techniques, materials, fittings and finishing. However, technical services such as potable water supply, sanitary, air quality, ventilation etc. are rated second among the factors that lead most frequently to design failure.

Data inclusiveness: The questionnaire identifies the different types of missing data that was associated with specific design failure. It shows little interest in environmental issues such as sustainable design, green building, and energy efficiency. Digital services and intelligent communication network were the least graded areas of interest on the survey matrix. The environmental quality of glass facades, surprisingly got the lowest place on the efficiency grades. The participants' responses showed rarity of interest in the philosophy of design such as architecture regionalism, traditional culture etc. (Table: 1).

Sources of data: the ${ }^{2 n d}$ questionnaire was used to answer a question, which asks about the sources from which lacking data has led to miss-informed design decisions? The questionnaire identifies the sources from which the missing data has led to missinformed design decisions. Less than half the surveyed architects have actually accessed the literature. Only 2 architects $(10 \%)$ had access to previous design appraisals, while 18 architects $(90 \%)$ relied heavily on personal tacit experience (Table : 2$)$.

Architects competency was measured on basis of both data inclusiveness and sources. The findings showed that most of the 8 architects who obtained $40 \%$ or less on the competency scale missed out on similar knowledge types including: energy efficiency and sustainability, and artificial intelligence. These architects also failed to acquire data from the same sources particularly from the literature, design documents, and design appraisal (Table: 3).

Data significance: the $4^{\text {th }}$ questionnaire requires architects to indicate the significance of 
the different types of data they collect and use in the design process. This questionnaire aims to show how the missing data has impacted design decisions, identifies the significance of missing data for specific design decisions (Table: 4).

The impact of missing data: this questionnaire identifies the significance of the impact the missing data has on design decisions (Table: 5).

Participation in POE evaluations: The survey has shown that architects, in general, rarely participate in POE efforts, and rarely have their design research data coded, recorded, or re-used in new design work (Tables: 6,7).

\subsection{The survey results}

The survey showed how missing data has been the most common reason of design failure. The analysis of the questionnaire findings has enabled the students to identify not only the missing data that was associated with specific observed failure, but also the impact of the missing data on understanding the problems of design and addressing them in a proper way. Using the questionnaire feedback enabled the students discover how inadequate acquisition of data contributes to miss-informed design decisions and ultimately leads to design failure.

Interviewing the architects was useful in reaching details of the missing data, which had it been available the failure may have been avoidable. Identifying the missing data, has directed the literature review and enabled the students to gain in-depth knowledge about the specific research problems in question.

The survey results have shown several reasons of missing data. A key reason seemed to be the architects own failure to obtain the views of the users before and after design. In many cases the users were not consulted ahead of design. Many architects admitted their failure to seek the views of the users before design or in post-occupancy. Only few $(20 \%)$ obtained the views of the users before design through informal talks. Lacking the views of the users both pre-and-post design process has been one major reason of design failure, the survey showed.

There are several other reasons of missing data the survey showed. One important reason is the lack of information or the difficulty to obtain data especially from official institutions. Many architects have expressed concern as a result of the repeated official refusal to give information or deny the availability of any information. Another reason is that the practicing architects rely most on tacit experience and the design knowledge they produce is rarely coded, documented or reused in new projects. A third reason is the lack of published design research. Many architects complained that access to research knowledge is not available, and the available international literature on the internet isin most cases not relevant to the local context.

\section{Conclusions}

The study has provided empirical evidence that assessing architects understanding of design problems can be made by measuring the quality of data they use in the design process. This has proved the validity of the study's assumption that the evaluation of design outcomes can be made by assessing the way architects use data to develop understanding of design problems. The results indicate the study has 
accomplished its objectives in developing and testing methods for the evaluation of design outcomes, and methods for assessing architects understanding of design problems.

The study reaches a conclusion that measuring the quality of the data architects may use to develop the knowledge base of design has proved to be a good practice not only for its ability to produce knowledge from the evaluation of design outcomes, but also its potential to develop analytic knowledge base for theory creation, in future research.

\section{References}

Friedman, K. (2000), Creating Design Knowledge: From Research into Practice, IDATER2000 Conference, Loughborough: Loughborough University. Available at: http://www.academia.edu [Accessed 31January 2018].

Herrmann, J. W. (2016), A framework for design theory and methodology research. The Institute for Systems Research, ISR Technical Report 2016-01, The Institute for Systems Research, Available at: http://drum.lib.umd/handle/1903/17454 [Accessed 15 February 2018].

Hillier, B. (2007), Space is the Machine: A Configurational Theory of Architecture, Electronic edition, Space Syntax, London, Available at: http://discovery.ucl.ac.uk/3881/1/SITMpdf [Accessed 15 October 2018].

Simon, H. (1969), The Sciences of the Artificial, MIT Press, Cambridge, Mass.

Vermaas, P. (2014). Design theories, Models and Their Testing: On the Scientific Status of Design Research, in Chakrabarti, A. and Blessing T.M. (eds.), An Anthology of theories and Models of Design. Springer-Verlag London, Available at: http://link.springer.com [Accessed 19 August 2018]. 